\title{
IDIOLOGI HUKUM PENDAFTARAN TANAH DALAM SISTEM HUKUM AGRARIA
}

\author{
Ita Surayya \\ Fakultas Hukum Universitas Mataram \\ Lombok, NTB, Indonesia \\ Email : itasurayya@unram.ac.id
}

\begin{abstract}
Abstrak
Pendaftaran tanah bukan hanya masalah administratif semata, melainkan didalamnya sarat dengan tarik-menarik kepentingan ideologi. Penelitian ini mempertanyakan dan mengkritisi pergeseran ideologi-hukum pendaftaran tanah dari instrumen reforma agraria menjadi instrumen pasar tanah.Metode penelitian menelusuri perubahan regulasi pendaftaran tanah, dan kemudian menyingkap kepentingan ideologi hukum yang menyebabkan pergeseran konfigurasi pendaftaran tanah. Di satu sisi, pendaftaran tanah sangat penting untuk memberikan kepastian hukum, tetapi di sisi lain, pendaftaran tanah yang lepas dari spirit reforma agraria akan memperlebar ketimpangan kepemilikan tanah, karena tanah-tanah yang telah bersertifikat akan lebih mudah berpindah tangan melalui mekanisme pasar.
\end{abstract}

Kata kunci: Pendaftaran Tanah; Ideologi; Instrumen; Reforma Agraria; Ketimpangan.

\begin{abstract}
Land registration is not only an administrative matter, but rather is filled with ideological interests. This study questions and criticizes the shifting ideology-law of land registration from agrarian reform instruments to land market instruments. The research method traces changes in land registration regulations, and then reveals the interests of legal ideologies that cause shifts in the configuration of land registration. On the one hand, land registration is very important to provide legal certainty, but on the other hand, land registration that is free from agrarian reform spirit will widen land ownership inequality, because land that has been certified will be easier to change hands through market mechanisms.
\end{abstract}

Keywords: Land Registry; Ideology; Instruments; Agrarian Reform; Inequality.

\section{A. PENDAHULUAN}

Banyak yang tidak tahu bahwa awalnya pendaftaran tanah sebagai instrumen untuk menyukseskan landreform yang salah satu programnya adalah redistribusi tanah. Pendaftaran tanah pada masa pelaksanaan landreform untuk mengetahui dan memastikan tanah-tanah berlebih atau melebihi batas maksimum pemilikan yang selanjutnya menjadi objek landreform. ${ }^{1}$

Bersamaan dengan jatuhnya pemerintahan Soekarno, program landreform dihentikan dan kebijakan agraria lebih pada fasilitasi lahan untuk investasi.Sejak itu orientasi pendaftaran tanah berubah, dari instrumen landrefom menjadi instrumen pasar tanah. Meski orientasi kebijakan agraria berubah, UU No. 5 tahun 1960 (UUPA) dan PP 10 tahun 1961 tidak sertamerta diubah, baru tahun 1997 terbit aturan baru tentang pendaftaran tanah menggantikan aturan lama yang dianggap tidak memadai.

Hukum tidak lahir dari ruang hampa, melainkan dipengaruhi oleh konstelasi politik, ekonomi, budaya, bahkan haluan ideologi negara tersebut. Tujuan penelitian ini mengkritisi

${ }^{1}$ Gunawan Wiradi, Reforma Agraria untuk Pemula, https://binadesa.org/gunawan-wiradi-reforma-agraria-untuk-pemula/, diakses pada tanggal 9 November 2019. 
pergeseran ideologi-hukum dibalik pendaftaran tanah guna memperjelas kemana orientasi pendaftaran tanah, apakah sebagai instrumen reforma agraria atau instrumen pasar tanah.

Berdasarkan uraian tersebut, penelitimemulai dengan menganalisis perubahan PP 10 tahun 1961 menjadi PP 24 tahun 1997 yang mengatur tentang pendaftaran tanah, kemudian menyingkap selubung idelogi-hukum di balik perubahan peraturan tersebut dengan rumusan masalah sebagai berikut;

Mengapa terjadi pergeseran fungsi pendaftaran tanah dari instrumen landreform menjadi instrumen pasar tanah?

\section{B. METODE PENELITIAN}

Penelitian ini menelusuri pergeseran konfigurasi hukum pendaftaran tanah yakni perubahan PP No. 10 tahun 1961 menjadi PP No. 24 tahun 1997 tentang Pendaftaran Tanah dengan membandingkan anatomi substansi kedua peraturan pemerintah tersebut. Peneliti juga mengkritisi perkembangan regulasi yang mendorong percepatan pendaftaran tanah belakangan ini. Peneliti kemudian melakukan wawancara dengan sejumlah aktivis agraria untuk lebih dalam menyingkap kepentingan ideologi hukum yang menyebabkan pergeseran konfigurasi pendaftaran tanah.

\section{PEMBAHASAN}

Perubahan dari Peraturan Pemerintah Nomor 10 tahun 1961 menjadi Peraturan Pemerintah Nomor 24 tahun 1997 tentang Pendaftaran Tanah sering dipahami hanya sebagai perubahan teknis peraturan perundang-undangan. Padahal hukum lahir bukan dari ruang hampa sehingga tidak dapat dilepaskan dari konteks sosio-historisnya.

Hal itu terlihat pada dua Peraturan Pemerintah (PP) tersebut, lahir pada masa konfigurasi ideologi dan politik hukum yang berbeda. PP 10 tahun 1961 tentang Pendaftaran Tanah lahir pada masa dimulainya program landreform pada zaman Orde Lama, sedangkan PP 24 tahun 1997 tentang Pendaftaran Tanah terbit pada masa ketergantungan Indonesia pada asing, krisis ekonomi menjelang jatuhnya rezim Orde Baru. Pengaruh Lembaga Keuangan Internasional pada masa itu disinyalir sangat besar mendorong perubahan peraturan pendaftaran tanah. ${ }^{2}$

Disebutkan tujuan dari Pendaftaran dalam Pasal 19 ayat 2 UUPA, sebagai berikut; ${ }^{3}$

1. Pengukuran, perpetaan dan pembukuan tanah.

2. Pendaftaran hak-hak atas tanah dan peralihan hak-hak tersebut

3. Pemberian surat-surat tanda bukti hak yang berlaku sebagai alat pembuktian yang kuat.

Membaca Pasal 19 UUPA tersebut secara skripturalistik, mereduksi makna pasal tersebut menjadi hanya bersifat teknis-administratif pendaftaran yakni mengatur pengukuran, perpetaan, pembukuan tanah hingga pemberian surat-surat tanda bukti hak ${ }^{4}$ yang berlaku sebagai alat pembuktian yang kuat. Padahal makna dibalik pendaftaran tanah tidak bisa dilepaskan dari spirit dan tujuan UUPA yakni, meletakkan landasan hukum berkenaan dengan redistribusi tanah yang monumental sekaligus revolusioner, salah satunya berupa perombakan struktur kepemilikan tanah yang timpang menjadi lebih berkeadilan sosial. UUPA antara lain mengatur

\footnotetext{
${ }^{2}$ Widodo Dwi Putro, Kritik Justice For The Poor, Jurnal Arena Hukum, Vol. 5 No. 2, 2012.

${ }^{3}$ Pasal 19 ayat 2 UUPA

${ }^{4}$ Jimmy Joses Sembiring.(2010). Panduan Mengurus Sertifikat Tanah. Jakarta: Visi Media, hlm. 21- 22
} 
pembatasan penguasaan tanah, kesempatan sama bagi setiap warga negara untuk memperoleh hak atas tanah, pengakuan hukum adat, serta warga negara asing tak punya hak milik.

Pasal 19 UUPA tersebut kemudian dijabarkan dan diatur lebih lanjut dengan Peraturan Pemerintah Nomor 10 Tahun 1961 tentang Pendaftaran. Tugas pendaftaran tanah, tidak hanya mencakup pengukuran, pemetaan maupun pendaftaran hak seseorang saja, tetapi juga untuk pelaksanaan konversi hak atas tanah dan informasi pertanahan, guna mempermudah jalannya landreform. Tugas Kantor Pertanahan dalam Undang-Undang Pokok Agraria (UUPA) juga termasuk menjaga agar prinsip Nasionalitas dari hak-hak atas tanah dilaksanakan dengan konsekuen. Demikian pula, pelaksanaan dari landreform Indonesia agar dilaksanakan dengan tegas, seperti larangan absentee, larangan pemilikan tanah yang luas (larangan lantifundia), larangan pengalihan hak atas tanah pertanian tanpa izin. Setelah dilakukan pendaftaran tanah, tahapan selanjutnya adalah penentuan tanah yang dikategorikan "tanah lebih" serta meredistribusikannya kepada petani tak bertanah.

Pemerintah sudah mulai melaksanakan program landeformsejak 24 September 1961 dengan membentuk panitia-panitia agraria yang bertugas melakukan pendaftaran pemilikan tanahtanah yang luasnya melebihi batas maksimun yang dibolehkan undang-undang serta tanahtanah guntai (absentee) pemiliknya tidak hadir. Tercatat sekitar dua puluh tujuh ribu orang pemilik sawah yang luas tanahnya melampaui batas maksimum dengan total luas tanah-lebih mencapai satu juta hektar yang siap dibagikan kembali (redistribusi) kepada para petani tak bertanah di sekitarnya. ${ }^{5}$

Pemerintah melakukan langkah-langkah revolusioner, yaitu: pendaftaran ulang tanah, penentuan tanah berlebih, mengatur kembali mengenai masalah bagi hasil serta puncak dari kebijakan revolusioner tersebut adalah redistribusi tanah. ${ }^{6}$

Redistribusi tanah dilator belakangi oleh keadaan dimana terdapat sebagian besar tanah pertanian yang luas dimiliki oleh segelintir tuan tanah. Di lain pihak adanya bagian- bagian tanah pertanian yang kecil (tidak luas) yang dimiliki oleh sebagian besar rakyat, khususnya para petani kecil dan penggarap yang sangat menggantungkan kehidupannya dari usaha pertanian yang dikelolanya dan dengan sungguh-sungguh memanfaatkannya. ${ }^{7}$

Redistribusi tanah yang diamanatkan UUPA No.5/1960 dilaksanakan melalui tiga tahap: ${ }^{8}$

1) Pendaftaran tanah di seluruh teritori RI berdasarkan Peraturan Pemerintah (PP) No. 10 tahun 1961, yang merupakan aturan turunan UU No.5/1960,

2) Setelah dilakukan pendaftaran, penentuan tanah yang dikategorikan "tanah lebih" serta pembagiannya kepada petani tak bertanah berdasarkan PP No 224 tahun 1961;

3) Pelaksanaan bagihasil produksipertanianyang berdasarkanUUNo.2/1960tentangperjanjian bagi hasil (PBH).

Melihat tahapan tersebut, kita sekarang menjadi tahu bahwa pendaftaran tanah pada masa pelaksanaan landreform, bukan hanya semata-mata memberikan kepastian hukum dan perlindungan hak bagi pemilik tanah. Tujuan pendaftaran tanah pada masa itu, untuk mengetahui dan memberi kepastian hukum tentang pemilikan dan penguasaan tanah. Tanah-tanah berlebih atau melebihi batas maksimum pemilikan selanjutnya menjadi objek landreform dibagikan kepada petani tak bertanah. Ini berarti, PP Nomor 10 Tahun 1961 tentang Pendaftaran Tanah merupakan "nyawa" dari kerja - kerja lembaga agraria di bidang pendaftaran tanah pada masa itu guna memperlancar program landreform.

\footnotetext{
${ }^{5}$ Gunawan Wiradi, Op.Cit.

${ }^{6}$ Ardi Susanto, Wakidi Wakidi, Syaiful M.(2014).Tinjauan Historis Penataan Ulang Masalah Agraria Pasca Pemberlakukan UUPA 1960, Jurnal Pesagi, Vol. 2 No. 3.

${ }^{7}$ Ibid.

${ }^{8}$ Diyan Isnaeni dan Suratman. (2018).Buku Reforma Agraria Land Reform dan Redistribusi Tanah di Indonesia, Intrans Publishing, hlm 3 - 25
} 
Pelaksanaan reforma agraria ini kemudian kandas dengan munculnya pemerintahan Orde Baru yang lebih bercorak kapitalis. Beberapa peraturan yang muncul di era Orde Baru substansinya justru bertentangan dengan semangat UUPA. Program pembangunan masa Orde Baru lebih mengandalkan investasi untuk mengejar angka pertumbuhan ekonomi yang tinggi, beberapa kemudahan diberikan kepada investor-investor yang masuk ke Indonesia, termasuk dalam hal mendapatkan hak pengelolaan tanah.

Pada awal Orde Baru berkuasa, Departemen Agraria diturunkan menjadi setingkat Direktorat Jenderal dilingkungan Departemen Dalam Negeri dan bagian yang menangani pendaftaran tanah disebut Direktorat Pendaftaran Tanah. Sejak itu pendaftaran tanah tidak lagi merupakan bagian dari landreform melainkan lebih masalah administratif pendaftaran. ${ }^{9}$

Pada masa Orde Baru, kebijakan pemerintah berubah yakni, mengintervensi langsung kebijakan-kebijakan tentang tanah yang semula visinya untuk perombakan kepemilikan tanah yang timpang melalui redistribusi tanah kepada petani penggarap (landreform) kemudian berubah menjadi tanah untuk kepentingan pembangunan dan investasi. ${ }^{10}$ Uniknya, UUPA yang menjadi dasar pelaksanaan landreform tidak diganti, secara legalitas UUPA tetap berlaku hingga sekarang tetapi "ditidurkan" (statutory dormancy). Demikian pula, PP 10 tahun 1961 memang tidak serta merta dicabut atau diamandemen, tetapi kebijakan dan pelaksanaan pendaftaran tanah berorientasi pada kepastian hak atas tanah untuk kepentingan pembangunan dan investasi. ${ }^{11}$

Beberapa tahun kemudian PP 10 Tahun 1961 diganti dengan PP 24 tahun 1997 tentang Pendaftaran Tanah. Dasar pergantian PP No 10 Tahun 1961 ini dapat dilihat dalam penjelasan PP No 24 Tahun 1997 pada bagian umumnya dinyatakan sebagai berikut;

"Dalam kenyataan pendaftaran tanah yang diselenggarakan berdasarkan Peraturan Pemerintah No 10 tahun 1961 tersebut selama lebih dari 35 tahun, belum cukup memberikan hasil yang memuaskan. Dari sekitar 55 juta bidang tanah hak yang memenuhi syarat untuk didaftar, baru lebih kurang 16,3 juta bidang yang sudah didaftar. Dalam pada itu melalui pewarisan, pemisahan dan pemberian-pemberian hak baru, jumlah tanah yang memenuhi syarat untuk didaftar selama pembangunan jangka panjang kedua diperkirakan akan meningkat menjadi sekitar 75 juta. Hal-hal yang merupakan kendala dalam pelaksanaan pendaftaran tanah, disamping kekurangan anggaran, alat dan tenaga, adalah keadaan objektif tanah-tanahnya sendiri yang selain jumlahnya besar dan tersebar diwilayah yang luas, sebagian besar penguasaannya tidak didukung oleh alat-alat pembuktian yang mudah diperoleh dan dapat dipercaya kebenarannya. Selain itu ketentuan hukum untuk dasar pelaksanaanya dirasakan belum cukup memberikan kemungkinan untuk terlaksananya pendaftaran dalam waktu yang singkat dengan hasil yang lebih memuaskan. Sehubungan dengan itu dalam rangka peningkatan dukungan yang lebih baik pada pembangunan nasional dengan memberikan kepastian hukum di bidang pertanahan, dipandang perlu untuk mengadakan penyempurnaan pada ketentuan yang mengatur pendaftaran tanah, yang pada kenyataannya tersebar pada banyak peraturan perundang-undangan."

${ }^{9}$ M. Nazir, Heri Priyatmoko, Muh Arif S.(2014)."Dari Dirjen Agraria Menuju Kementerian Agraria: Perjalanan Sejarah Kelembagaan Agraria, 1948-1965”, Penelitian Sistematis 2014, PPPM-STPN,. Lihat juga, Sutaryono, Sejarah kelembagaan Agraria, Dari Kementerian Menjadi Direktorat Jenderal, 1961-1970 an, makalah, tanpa tahun.

${ }^{10}$ Noer Fauzi Rachman.(2011).Land Reform dari Masa ke Masa. Perjalanan Kebijakan Pertanahan 1945-2009, Yogyakarta: Tanah Air Beta.

${ }^{11}$ Noer Fauzi dan Dadang Juliantara.(2000).Menyatakan Keadilan Agraria, Badan Pelaksana Konsorsium Pembaruan Agraria,hlm. 293-331. 
Alasan perubahan itu, PP 10 tahun 1961 dipandang tidak dapat lagi sepenuhnya mendukung tercapainya hasil yang lebih nyata pada pembangunan nasional, sehingga perlu dilakukan penyempurnaan, ${ }^{12}$ maka pemerintah mengeluarkan PP No. 24 tahun 1997 tentang Pendaftaran Tanah. Tujuan pendaftaran tanah dalam PP 24 tahun 1997 tersebut dapat ditemukan dalam ketentuan Pasal 3 sebagai berikut; ${ }^{13}$

a. Untuk memberikan kepastian hukum dan perlindungan hukum kepada pemegang hak atas suatu bidang tanah, satuan rumah susun dan hak-hak lain yang terdaftar agar dengan mudah dapat membuktikan dirinya sebagai pemegang hak yang bersangkutan,

b. Untuk menyediakan informasi kepada pihak-pihak yang berkepentingan termasuk pemerintah agar dengan mudah dapat memperoleh data yang diperlukan dalam mengadakan perbuatan hukum mengenai bidang-bidang tanah dan satuan- satuan rumah susun yang terdaftar;

c. Untuk terselenggaranya tertib administrasi pertanahan.

Dalam Pembangunan Jangka Panjang yang berkesinambungan peranan tanah bagi pemenuhan berbagai keperluan akan meningkat, baik sebagai tempat bermukim maupun untuk kegiatan usaha. Sehubungan dengan itu akan meningkat pula kebutuhan akan dukungan berupa jaminan kepastian hukum di bidang pertanahan. Pemberian jaminan kepastian hukum di bidang pertanahan, pertama-tama memerlukan tersedianya perangkat hukum yang tertulis, lengkap dan jelas yang dilaksanakan secara konsisten sesuai dengan jiwa dan isi ketentuan-ketentuannya. Selain itu dalam menghadapi kasus-kasus konkret diperlukan juga terselenggaranya pendaftaran tanah yang memungkinkan bagi para pemegang hak atas tanah untuk dengan mudah membuktikan haknya atas tanah yang dikuasainya. Demikian pula, bagi para pihak yang berkepentingan, seperti calon pembeli dan calon kreditor, untuk memperoleh keterangan yang diperlukan mengenai tanah yang menjadi obyek perbuatan hukum yang akan dilakukan. ${ }^{14}$

Pendaftaran tanah, menurut konsep PP Nomor 24 Tahun 1997, akan menghasilkan surat-surat tanda bukti hak yang berlaku sebagai pembuktian yang kuat tetapi bukan mutlak, yakni sistem negatif bertendensi positif. kelemahan sistem pendaftaran tanah yang negatif, yakni bahwa apa yang tertuang dalam sertifikat dianggap benar sampai adanya yang menyatakan sebaliknya, tidak akan memberikan kepastian hukum dan perlindungan hukum kepada pemegang hak atas tanah yang namanya tertulis dalam sertifikat. Setiap saat pihak yang merasa berhak dan dapat membuktikan kepemilikannya, dapat mengajukan permohonan pembatalan sertifikat tersebut.

Tentu bagi investor, PP 24 tahun 1997, masih dianggap mempunyai kelemahan, karena sistem negatif bertendensi positif belum sepenuhnya menjamin kepastian hukum. Padahal bagi investor dan pasar, kepastian hukum itu masalah sensitif ${ }^{15}$ karena mereka tidak ingin menghadapi gugatan sengketa pertanahan dikemudian hari.

Karena itu, Pemerintahan Jokowi melalui Rencana Pembangunan Jangka Menengah Nasional (RPJMN) 2015-2019 telah berencana untuk merubah sistem pendaftaran tanah di Indonesia, dari sistem pendaftaran tanah publikasi negatif menjadi sistem publikasi positif. Sistem pendaftaran tanah publikasi positif diyakini dapat memberikan kepastian hukum hak atas tanah secara absolut. Pemerintah juga menjamin kebenaran semua informasi yang tertulis dalam sertifikat hak atas tanah. Apabila terjadi kesalahan administrasi oleh pemerintah (misalnya sertifikat ganda), pemerintah akan memberikan dana kompensasi atau ganti kerugian atas kesalahan administrasi tersebut. Penggunaan sistem ini juga diharapkan dapat

\footnotetext{
${ }^{12}$ Adrian Sutedi, Peralihan Hak Atas Tanah dan Pendaftarannya, Jakarta: Sinar Gafika, hlm.114.

${ }^{13}$ Ali Achmad Chomzah.(2004).Hukum Agraia jilid 2,Jakarta: Prestasi Pustaka,hlm. 116.

${ }^{14}$ Peraturan Pemerintah Republik Indonesia Nomor 24 Tahun 1997 Tentang Pendaftaran Tanah.

${ }^{15}$ Idham, Et.All.(2018). Political Paradigm of Complete Systematic Land Registration Law to Actualize Economic Growth Compliance in Batam City, Indonesia, Journal of Art and Humanities, Vol. 7 no.10.
} 
mengurangi permasalahan terkait pertanahan serta mendorong terciptanya iklim investasi dan iklim ekonomi yang kondusif yang dapat memberikan peningkatan daya saing perekonomian nasional didunia. ${ }^{16}$

Pada pertengahan Februari 2018, Presiden Joko Widodo resmi menandatangani Inpres Nomor 2/2018 tentang Percepatan Pendaftaran Tanah Sistematis Lengkap (PTSL). Inpres ini keluar guna mempercepat seluruh bidang tanah di Indonesia, diklaim merupakan mandat Pasal 19UU Pokok Agraria 1960. Percepatan pendaftaran tanah ini dicanangkan sampai 2025.

Inpres ini ditujukan kepada Menteri Agraria dan Tata Ruang/Kepala Badan Pertanahan Nasional, Menteri Lingkungan Hidup dan Kehutanan, dan Menteri Pekerjaan Umum dan Perumahan Rakyat (PUPR). Juga Menteri Dalam Negeri, Menteri Badan Usaha Milik Negara (BUMN), Menteri Keuangan, Menteri Desa, Pembangunan Daerah Tertinggal, dan Transmigrasi, Kapolri, Jaksa Agung. Ia juga ditujukan kepada Kepala Lembaga Kebijakan Pengadaan Barang dan Jasa Pemerintah, Kepala Lembaga Penerbangan dan Antariksa Nasional, Kepala Badan Informasi Geospasial, para gubernur dan bupati/walikota. ${ }^{17}$

Presiden menginstruksikan agar mengambil langkah-langkah yang diperlukan sesuai dengan tugas, fungsi, dan kewenangan masing-masing dalam rangka pelaksanaan percepatan Pendaftaran Tanah secara Sistematis Lengkap di seluruh wilayah Indonesia sebagai Gerakan Nasional dengan tujuan utama agar terwujudnya pendaftaran tanah secara lengkap di seluruh wilayah Indonesia dalam rangka mendukung Proyek Strategis Nasional.

Pelaksanaan PTSL berbeda dengan program pemerintah sebelumnya seperti Proyek Administrasi Pertanahan (PAP), Land Management and Policy Development Project (LMPDP) atau Proyek Ajudikasi, Larasita, dan Program Nasional Agraria (Prona). PTSL berbeda dengan program-program sebelumnya karena Presiden memantau, mengevaluasi bahkan berperan langsung dalam pembagian sertifikatnya kepada masyarakat. ${ }^{18}$

Di satu sisi keputusan inpres tentang PTSL patut diapresiasi. Pendaftaran tanah secara nasional dan sistematis sangat perlu mengingat banyak masalah pertanahan, terutama konflik agraria dan tumpang tindih klaim kepemilikan tanah. Kondisi ini terjadi karena ketiadaan informasi dan data akurat dan faktual tentang penguasaan, pemilikan, dan penggunaan tanah di Indonesia.

Meskipun begitu, disisi lain, PTSL akan jadi bagian dari masalah apabila pendaftaran hanya bersifat administratif percepatan sertifikasi tanah. Masyarakat senang dengan program percepatan sertifikasi tanah, padahal Inpres tersebut akan mempercepat proses liberalisasi pasar tanah. Implikasinya, tanah-tanah pertanian yang telah bersertifikat akan lebih mudah berpindah tangan ke orang-orang kaya yang bukan petani melalui mekanisme pasar sehingga memperlebar ketimpangan struktur agraria dan mempercepat alih fungsi lahan. ${ }^{19}$

PTSL seharusnya bisa jadi mekanisme pemeriksaan pertanahan nasional untuk melihat ketimpangan struktur agraria di berbagai wilayah Indonesia. Pemerintah melalui program PTSL seharusnya memeriksa tumpang tindih penguasaan dan penggunaan tanah di lapangan. Dengan begitu, PTSL akan berkontribusi besar terhadap masalah administrasi pertanahan yang

${ }^{16} \mathrm{https}: / /$ www.bappenas.go.id/files/kajian trp/Kajian_Persiapan_Perubahan_Sistem_Pendaftaran_Tanah_Publikasi_Positif_di_Indonesia.pdf, diakses pada tanggal 9 November 2019

${ }^{17}$ https://setkab.go.id/presiden-jokowi-teken-inpres-percepatan-pendaftaran-tanah-sistematis-lengkap/, diakses pada tanggal 9 November 2019

${ }^{18}$ Isdiyana Kusuma Ayu,(2019),Problematika Pelaksanaan Pendaftaran Tanah Melalui Pendaftaran Tanah Sistematis Lengkap di Kota Batu, Jurnal Legality, Vol 27 No. 1.

${ }^{19}$ Peneliti melakukan menyimak dan wawancara secara informal dengan para aktivis agraria, akademisi, organisasi tani, dan berbagai organisasi masyarakat sipil pada 13 Agustus 2019 di Jakarta pada saat konferensi pers Pernyataan Sikap Penolakan terhadap RUU Pertanahan yang sedang dibahas DPR dan pemerintah. 
masih lemah. Sekaligus, PTSL menjadi basis perubahan yang hendak dijalankan pemerintah dalam kerangka reforma agraria.

\section{KESIMPULAN}

Pendaftaran tanah bukan hanya masalah administratif semata, melainkan didalamnya sarat dengan tarik-menarik kepentingan ideologi-hukum. Pergeseran konfigurasi pendaftaran tanah ditentukan basis ideologi-hukumnya. Pada masa awal lahirnya UUPA, pendaftaran tanah didayagunakan sebagai instrumen landreform untuk memastikan tanah-tanah yang melampaui batas menjadi objek redistribusi tanah. Pelaksanaan reforma agraria ini kemudian kandas bersamaan berubahnya haluan ideologi hukum yang lebih bercorak kapitalis sehingga fungsi pendaftaran tanah berubah menjadi instrumen pasar tanah. Di satu sisi, pendaftaran tanah secara nasional sangat perlu untuk memberikan kepastian hukum, menyediakan data akurat, sehingga mencegah sengketa agraria dan tumpang tindih klaim kepemilikan tanah. Tetapi di sisi lain, pendaftaran tanahyang lepas dari spirit reforma agraria akan memperlebar ketimpangan kepemilikan tanah, karena tanah-tanah yang telah bersertifikat akan lebih mudah berpindah tangan ke orang-orang kaya melalui mekanisme pasar.

\section{Daftar Pustaka}

\section{Buku}

Gunawan Wiradi, Reforma Agraria untuk Pemula, https://binadesa.org/gunawan-wiradireforma-agraria-untuk-pemula/, diakses pada tanggal 9 November 2019.

Widodo Dwi Putro, Kritik Justice For The Poor, Jurnal Arena Hukum, Vol. 5 No. 2, 2012.

Jimmy Joses Sembiring, Panduan Mengurus Sertifikat Tanah, Visi Media, Jakarta, 2010.

Ardi Susanto, Wakidi Wakidi, Syaiful M, Tinjauan Historis Penataan Ulang Masalah Agraria Pasca Pemberlakukan UUPA 1960, Jurnal Pesagi, Vol. 2 No. 3, 2014

Diyan Isnaeni dan Suratman, Buku Reforma Agraria Land Reform dan Redistribusi Tanah di Indonesia, Intrans Publishing, 2018.

M. Nazir, Heri Priyatmoko, Muh Arif S, "Dari Dirjen Agraria Menuju Kementerian Agraria: Perjalanan Sejarah Kelembagaan Agraria, 1948-1965”, Penelitian Sistematis 2014, PPPM-STPN, 2014.

Sutaryono, Sejarah kelembagaan Agraria, Dari Kementerian Menjadi Direktorat Jenderal, 1961-1970 an, makalah, tanpa tahun.

Noer Fauzi Rachman, Land Reform dari Masa ke Masa. Perjalanan Kebijakan Pertanahan 1945-2009, Yogyakarta: Tanah Air Beta, 2011.

Noer Fauzi dan Dadang Juliantara, Menyatakan Keadilan Agraria, Badan Pelaksana Konsorsium Pembaruan Agraria, 2000..

Adrian Sutedi, Peralihan Hak Atas Tanah danPendaftarannya,, Sinar Gafika, Jakarta.

Ali Achmad Chomzah, Hukum Agraria jilid 2, Jakarta: Prestasi Pustaka, 2004.

Idham, Et.All, Political Paradigm of Complete Systematic Land Registration Law to Actualize

Economic Growth Compliance in Batam City, Indonesia, Journal of Art and Humanities, Vol. 7 no. 10, 2018

Isdiyana Kusuma Ayu, Problematika Pelaksanaan Pendaftaran Tanah Melalui Pendaftaran 
Tanah Sistematis Lengkap di Kota Batu, Jurnal Legality, Vol 27 No. 1, 2019.

Peneliti melakukan menyimak dan wawancara secara informal dengan para aktivis agraria, akademisi, organisasi tani, dan berbagai organisasi masyarakat sipil pada 13 Agustus 2019 di Jakarta pada saat konferensi pers Pernyataan Sikap Penolakan terhadap RUU Pertanahan yang sedang dibahas DPR dan pemerintah.

\section{Peraturan Perundang-undangan}

Pasal 19 ayat 2 UUPA

Peraturan Pemerintah Republik Indonesia Nomor 24 Tahun 1997 Tentang Pendaftaran Tanah.

\section{Internet}

https://www.bappenas.go.id/files/kajian-trp/Kajian_Persiapan_Perubahan_Sistem Pendaftaran_Tanah_Publikasi_Positif_di_Indonesia.pdf, diakses pada tanggal 9 November 2019

https://setkab.go.id/presiden-jokowi-teken-inpres-percepatan-pendaftaran-tanah-sistematislengkap/, diakses pada tanggal 9 November 2019 